\title{
Angiotensin Converting Enzyme Insertion/Deletion Gene Polymorphisms in Leukemic Hematopoiesis
}

\author{
Ibrahim AKALIN ${ }^{1}$, Ebru KOCA ${ }^{2}$, Halil G. KARABULUT ${ }^{1}$, Ibrahim C. HAZNEDAROGLU ${ }^{2}$, \\ Deniz CETINER ${ }^{2}$, Mutlu HAYRAN ${ }^{3}$, Ibrahim K. ONAL ${ }^{4}$, Osman I. OZCEBE ${ }^{2}$, Ajlan TUKUN ${ }^{1}$
}

\author{
${ }^{1}$ Ankara University Faculty of Medicine, Department of Medical Genetics \\ ${ }^{2}$ Ankara University Faculty of Medicine Department of Internal Medicine, Hematology Unit \\ ${ }^{3}$ Ankara University Faculty of Medicine, Department of Preventive Oncology \\ ${ }^{4}$ Hacettepe University Faculty of Medicine, Department of Internal Medicine, Ankara, TURKEY
}

\begin{abstract}
Local bone marrow renin-angiotensin system (RAS) is an autocrine-paracrine system affecting normal and neoplastic hematopoiesis. Angiotensin converting enzyme (ACE) converts angiotensinogen-I to its physiologically active peptide angiotensinII, which stimulates proliferation and differentiation of hematopoietic stem cells through angiotensin II type 1 receptors. We investigated the ACE insertion/deletion (I/D) gene polymorphisms in patients with hematological malignancies including acute and chronic leukemia, myelodysplastic syndrome and multiple myeloma. Our results showed that $80.4 \%$ of the patients represented ID/II genotype, whereas it was 55.9\% of the control group and 3.2 fold increased disease risk in the existence of insertion allele (ID/II). This is the first study demonstrating possible effects of ACE I/D gene polymorphism of the local bone marrow RAS components on leukemic hematopoiesis.
\end{abstract}

Keywords: Angiotensin converting enzyme, Local renin-angiotensin system, ACE I/D gene polymorphism, Angiotensin II, Leukemic hematopoiesis

\section{ÖZET}

Lösemik Hematopoezde Kemik iliği Anjiotensin II Tip I Reseptör Gen ve Anjiotensin Dönüştürücü Enzim (ACE) İnsersiyon/Delesyon (I/D) Gen Polimorfizmleri

Lokal kemik iliği renin anjiotensin sistemi (RAS) normal ve neoplastik hematopoezi etkileyen otokrin ve parakrin bir sistemdir. Anjiotensin dönüştürücü enzim (ACE) anjiotensinojen-l'i kendisinin fizyolojik olarak aktif peptide olan anjiotensin Il'ye dönüştürür ki, bu hemetopoetik kök hücrelerin çoğalmasını ve farklılaşmasını anjiotensin tip 1 reseptörleri üzerinden uyarır. Biz ACE insersyon/delesyon gen polimorfizmlerini akut ve kronik lösemi, myelodisplastik sendrom ve multiple myeloma gibi hematoIojik malignasili hastalarda araştırdık. Çalışma sonuçlarımıza göre hastaların \% 80.4'ü ID/Il genotipi gösterirken bu oran kontrol grubunda \% 55.9 olarak bulundu ve insersiyon alleli varlığında (ID/II) 3.2 kat artmış hastalık riski saptandı. Bu lokal kemik ilği RAS üyelerinden ACE'nin I/D gen polimorfizminin lösemik hematopoezdeki olası etkisini gösteren ilk çalışmadır.

Anahtar Kelimeler: Anjiotensin dönüştürücü enzim, Lokal renin-anjiotensin sistemi, ACE I/D gen polimorfizmi,

Anjiotensin II, Lösemik hematopoez 


\section{INTRODUCTION}

The new frontiers of the renin-angiotensin system (RAS) include organ-, tissue-, and even cell-based systems within the human body exhibiting autocrine, paracrine, endocrine and intracrine actions. ${ }^{1}$ Presence of a local bone marrow RAS, affecting physiological and neoplastic blood cell production, has been evolved as a novel hypothesis in the past decade..$^{2-4}$ The forthcoming studies gave countenance to the potent stimulatory affect of angiotensin II in physiological hematopoiesis accordingly in an autocrine-paracrine manner by the findings of increased expression of RAS components such as renin, angiotensinogen and anjiotensin II it-self and its type-1 receptors (AT1R) on hematopoietic stem and precursor cells. ${ }^{5,6}$ Angiotensin II stimulates the proliferation of bone marrow hematopoietic progenitors and umbilical cord blood cells. ${ }^{7}$ Likewise, over-expression of RAS components were reported in leukemic hematopoiesis $^{6}$ and on acute myeloid leukemia cells. ${ }^{8-10}$ Hence, the context of the local bone marrow RAS represents the clues for being a potent autocrin/paracrin system affecting both normal and neoplastic hematopoiesis.

One of the cornerstone enzymes in the RAS is angiotensin-1 converting enzyme (ACE), which converts the angiotensinogen-I to its physiologically active peptide angiotensin-II. As a zinc metallopeptidase enzyme; ACE may play a major role in numerous physiological activities including cellular proliferation and metabolism of numerous other biologically active peptides owing to broad enzymatic specificity in the body. The encoding ACE gene is localized to long arm of the 17th chromosome (17q23.3) and responsible for the production of two isoenzymes- somatic and testicular form- according to alternative splicing of the single but duplicated ACE gene..$^{11,12}$ Additionally, it was identified that there were membrane-bound and circulating forms of the sACE enzyme. The membrane-bound form is present on various cell types, including vascular endothelial cells, epithelial cells, neuronal cells, macrophages and male germinal cells, in which C-domain of the sACE has found to be related to RAS by taking role in conversion of angiotensin-I to angiotensin-II and hydrolyses of bradykinin. ${ }^{13}$ However, the circulating form of the ACE has found to be present in such biological fluids as plasma, amniotic and seminal fluids.
Differences in the circulating ACE levels among individuals have been determined in part by a polymorphic gene which has a major effect on the phenotype. ${ }^{14}$ The gene responsible for this effect was ACE gene itself. An insertion/deletion (I/D) polymorphism located in the intron 16 of the ACE gene has found to be associated with differences of the plasma levels of ACE in the group of healthy subjects. ${ }^{14}$ Moreover, I/D polymorphism of the ACE gene has been linked to coronary heart disease since subjects of the homogenous deletion genotype (DD) gave the impression of increasing myocardial infarction risk. ${ }^{15}$ ACE has also been found in human monocytes/macrophages, and in the T-lymphocyte population. Thus, ACE likewise other ectopeptidases, may participate in the regulation of lymphocyte functions. The T-lymphocyte ACE levels of a given subject are highly reproducible when measured on two different occasions, but may vary widely between individuals in association with $\mathrm{I} / \mathrm{D}$ polymorphism of the ACE gene.

Since plasma ACE has been thought to originate from endothelial cells and ACE was mostly a membrane-bound ecto-enzyme on those cells as on the other cell types, wherever it has been synthesized these observations indicated that the level of ACE expression was genetically determined. Therefore, in this study, we investigated ACE I/D gene polymorphisms, which might affect the behavior of the local RAS in hematological neoplastic disorders.

\section{MATERIALS AND METHODS}

Patients and DNA Isolation: In order to explore the ACE I/D gene polymorphisms, bone marrow samples of patients diagnosed with AML, CML, ALL, CLL, MM and MDS collected during their assessment and diagnosis at Hacettepe University Faculty of Medicine, Department of Internal Medicine, Hematology Unit in Ankara, Turkey and peripheral blood samples of healthy people were studied.

The genetic studies of the samples including isolation of Deoxyribonucleic acids (DNA), polymerase chain-reaction (PCR) and gel electrophoresis were done at Molecular Genetics Laboratory of Ankara University Faculty of Medicine, Department of Medical Genetics in Ankara, Turkey. DNAs of the patients were extracted from $3 \mathrm{ml}$ bone marrow biopsy 


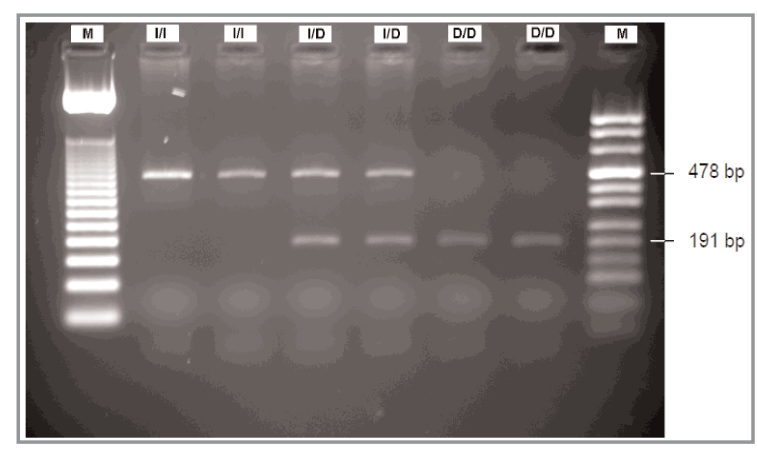

Figure 1. ACE I/D gene polymorphisms at $2 \%$ agarose gel visualized by Kodak Gel Logic 200.

I: Insertion, D: Deletion, M: Marker (Ladder)

samples which were obtained for routine cytogenetic examination either drawn by heparinized syringe or into EDTA containing tubes. Control group DNAs were extracted from peripheral blood samples drawn into 5-ml tubes containing EDTA. DNAs were isolated from all samples by proteinase $\mathrm{K}$ digestion, salt extraction, and ethanol precipitation method following standard protocols.

All patients provided written informed consent and study was approved by Hacettepe University Faculty of Medicine Research Ethical Committee (TBK 05/13-8).

Determination of ACE Genotypes: ACE I/D gene polymorphism has been investigated on the basis of PCR amplification of intron 16 of the ACE gene using forward and reverse primers, 5'-CCACTCCCATCCTTTCTCC-3' and 5'-GGCCATCACATTCGTCAGA-3', respectively, as previously described (16). After initial denaturation at $93^{\circ} \mathrm{C}$ for $3 \mathrm{~min} ; 30$ cycles of $92^{\circ} \mathrm{C}$ for $1 \mathrm{~min}, 57^{\circ} \mathrm{C}$ for $1 \mathrm{~min}$, and $72^{\circ} \mathrm{C}$ for $1 \mathrm{~min}$. were performed with a final extension at $72^{\circ} \mathrm{C}$ for $7 \mathrm{~min}$. PCR products were run on $2 \%$ agarose gel and visualized by Kodak Gel Logic 200 (Raytest GmbH, Straubenhardt, Germany) (Figure 1). All samples were studied twice. Because the $D$ allele is preferentially amplified where the I allele is sometimes suppressed, samples found to have DD genotype were subjected to a second, independent PCR amplification with an insertion-specific primer as described previously. ${ }^{17}$

\begin{tabular}{|lll|}
\hline \multicolumn{3}{|c|}{ Table 1. Diagnostic features of patients } \\
\hline \multicolumn{3}{|c|}{ Patients } \\
\cline { 2 - 3 } (n) & (\%) \\
\hline MDS & 7 & 15.2 \\
AML & 10 & 21.7 \\
Minimal Changed & 1 & \\
Myelomonocytic & 3 & \\
Monoblastic & 2 & \\
t(8;21) + & 1 & \\
Multilineage Displasia & 1 & \\
Unclassified & 1 & \\
With Maturation & 10 & 17.4 \\
ALL & 8 & \\
T cell phenotype & 1 & 37 \\
B cell phenotype & 7 & \\
CML & 17 \\
Chronic Phase & 16 & 2.2 \\
Accelerated phase & 1 & 6.5 \\
CLL & 1 & 100 \\
MM & 3 & \\
TOTAL & 46 & \\
\hline & & \\
& & \\
\end{tabular}

Statistical Evaluation: In order to compare the frequency of genotypes within the groups, the Chi-square test and the Fisher's exact test for multiple groups were used within SPSS (Statistical Package for the Social Sciences Program) program for Windows version 11.5. Additionally, (Kolmogorov-Smirnov Test) was used for distribution of age and the likelihood ratio test ( $\mathrm{G}$ statistic) was used to assess the agreement between genotypes observed and those predicted by the Hardy-Weinberg equilibrium. The $\mathrm{p}$ value less than 0.05 has been considered as statistically significant $(\mathrm{p}<0.05)$.

\section{RESULTS}

In order to evaluate the ACE I/D gene frequencies in 46 patients with leukemia and 59 healthy people were enrolled to the study between November 2005 and October 2007. Diagnostic features of patients are given in Table $1.23(59 \%)$ of the patients and 27 (46\%) of the control group were male. Median age of patient group was greater than control group (49 years 
Table 2. ACE I/D genotype frequencies in leukemic disorders.

\begin{tabular}{|lllll|}
\hline & & \multicolumn{2}{l}{ ACE Polymorphism } & Total \\
\cline { 3 - 5 } & & DD & ID/II & \\
\hline Control & $(\mathrm{n})$ & 26 & 33 & 59 \\
& $(\%)$ & 44.1 & 55.9 & 100 \\
Patients & $(\mathrm{n})$ & 9 & 37 & 46 \\
& $(\%)$ & 19.6 & 80.4 & 100 \\
\hline
\end{tabular}

old [range, 17-81] vs. 30 years old [range, 17-78], respectively) However, the distribution of age was homogenous in each group (Kolmogorov-Smirnov Test). The Hardy-Weinberg equilibrium was in agreement using likelihood ratio test $(\mathrm{G}$ statistic; $\mathrm{G} 2=$ 0.039 , freedom degree $=1$ and $\mathrm{p}=0.843$ ).

ACE ID/II genotype frequency was significantly increased in patients with hematological disorders. Overall ID/II genotype frequencies was found in $80.4 \%$ of the patients while it was $55.9 \%$ in the control group. There was significantly higher I allele $(p=0.008)$ in 46 patients compared to control group. Disease risk has found 3.2 times increased in patients who were carrying I allele (ID or II) $(\mathrm{p}=0.008$, OR: 3.2[95\% C.I., 1.3-7.9]) (Table 2). Moreover, I allele (II or ID) carrying leukemia (CML, AML and ALL) patients were significantly higher compared to only D allele (DD) carriers ( $<<0.001)$ (Table 3 and 4).

ACE ID/II genotype frequency was not different in patients with CML, AML or ALL. When we compa- red the patients with CML, AML and ALL in order to find out the possible ACE I/D polymorphism differences, there was no statistically significant difference between each diagnoses group $(\mathrm{p}=1.0$, multiple groups Fisher Test) (Table 3-4). Among them; $88.2 \%$ of CML, $90 \%$ of AML and $87.5 \%$ of ALL patients were carrying I allele.

MDS patients were carrying similar insertion allele frequency with control group unlike leukemia patients. MDS patients were carrying very similar frequency of I allele compared to control group (57.1\% to 55.9 $\%$, respectively). The difference was not statistically significant $(\mathrm{p}>0.05)$. However, insertion allele frequency in leukemia patients $(88.9 \%)$ was significantly increased compared to MDS (57.1\%) ( $\mathrm{p}=$ 0.003 ). Additionally, presence of I allele had increased leukemia risk 6.3 times $(\mathrm{p}=0.001$ and [odds ratio: 6.3; 95\% C.I., 1.98-20.1]) (Figure 2).

Insertion allele increased the leukemia risk in patients under 50 years old: I allele frequency under the

Table 3. ACE I/D gene polymorphism of CML, AML and ALL patients.

\begin{tabular}{|c|c|c|c|c|}
\hline & & \multicolumn{2}{|c|}{ ACE Polymorphism } & \multirow[t]{2}{*}{ Total } \\
\hline & & DD & ID/II & \\
\hline \multirow[t]{2}{*}{ ALL } & (n) & 1 & 7 & 8 \\
\hline & $\%$ within leukemias & 12.5 & 87.5 & 100 \\
\hline \multirow[t]{2}{*}{ AML } & (n) & 1 & 9 & 10 \\
\hline & $\%$ within leukemias & 10 & 90 & 100 \\
\hline \multirow[t]{2}{*}{$\mathrm{CML}$} & (n) & 2 & 15 & 17 \\
\hline & $\%$ within leukemias & 11.8 & 88.2 & 100 \\
\hline \multirow[t]{2}{*}{ Total } & (n) & 4 & 31 & 35 \\
\hline & $\%$ within leukemias & 11.4 & 88.6 & 100 \\
\hline
\end{tabular}


Table 4. ACE I/D polymorphism differences of leukemia subgroups

\begin{tabular}{|llll|}
\hline Diagnosis & $\begin{array}{l}\text { I allel carrier } \\
\text { (genotype ID/II) }\end{array}$ & $\begin{array}{l}\text { Non-I (\%) } \\
\text { (genotype DD) } \mathbf{n} \text { (\%) }\end{array}$ & p value \\
\hline Leukemia (ALL, AML, CML) & $35(85.4)$ & $6(14.6)$ & $<0.001$ \\
ALL & $7(87.5)$ & $1(12.5)$ & 0.034 \\
AML & $9(90.0)$ & $1(10.0)$ & 0.011 \\
CML & $15(88.2)$ & $2(11.8)$ & 0.002 \\
Control & $33(55.9)$ & $26(44.1)$ & 0.508 \\
\hline
\end{tabular}

age of 50 were $83.3 \%$ in patients with hematological malignancies and $54.5 \%$ in the control group. I allele increased leukemia risk 4.2 times in this age group $(\mathrm{p}=0.015)$ [OR: 4.2; 95\% CI, 1.26-13.8]. I allele frequency was not different between patients and control group over 50 years old $(77.3 \%$ and $75 \%$ respectively, $\mathrm{p}=1.0$ ) (Table 5).

\section{DISCUSSION}

In this study, we investigated I/D gene polymorphism of the ACE gene coding for ACE by polymerase chain reaction within leukemia (CML, AML, ALL, CLL, patients including MDS and MM. To our knowledge, this is the first study to provide the evidence that ACE ID/II gene polymorphisms may be linked to the development of leukemia as a clue of activated local RAS in bone marrow during leukemogenesis.
Following the introduction of I/D gene polymorphism in the literature by Rigat et al. (14) , "D" allele has been reported to be related to increased serum enzyme levels compared to "I" allele $(14 ; 18)$. The latter described as an insertional mutation, present in the intron 16 of the ACE gene, that caused by retrotransposition of 287 basepair of Alu repeat element. ${ }^{19}$ Since, Suehiro et al. ${ }^{20}$ reported that D allele had increased the ACE mRNA levels, it was also found to be a potent risk factor for cardiovascular diseases particularly on myocardial infarction in Turkish population..$^{20,21}$ Production of angiotension-II is increased as a result of increased serum ACE levels (15; 22-24). Reasonably thereafter increased Angiotensin-II causes vasoconstriction on renal vascular smooth muscle, increase fluid and electrolyte reuptake from renal tubule cells and finally augments the endocrine response by stimulating aldosteron and vasopressin release. Although, the latter has currently been ac-

Table 5. ACE I/D gene polymorphism and age distribution (cut off point is 50 years old).

\begin{tabular}{|c|c|c|c|c|c|}
\hline & & \multicolumn{2}{|c|}{ ACE I/D gene polymorphism } & & \multirow[t]{2}{*}{ Tota } \\
\hline & & DD & ID/DD & & \\
\hline \multirow[t]{4}{*}{$\leq 50$ years old } & Control & (n) & 25 & 30 & 55 \\
\hline & & $\%$ & 45.5 & 54.5 & 100 \\
\hline & Patients & (n) & 4 & 20 & 24 \\
\hline & & $\%$ & 16.7 & 83.3 & 100 \\
\hline \multirow[t]{4}{*}{$>50$ years old } & Control & (n) & 1 & 3 & 4 \\
\hline & & $\%$ & 25.0 & 75.0 & 100 \\
\hline & Patients & (n) & 5 & 17 & 22 \\
\hline & & $\%$ & 22.7 & 77.3 & 100 \\
\hline
\end{tabular}


cepted as a causative concept for D allele to be a cardiovascular risk factor, only few studies reported that there was no significant relationship between the ACE I/D gene polymorphism and serum angiotensin II levels or increased plasma ACE levels and angiotensin II levels. ${ }^{25-29}$ These findings once more increase the importance of local ACE levels that could have much more potency on the Ang II levels within the tissues rather than in circulation..$^{30}$

On the other hand, several investigators have been interested on the effects of ACE gene polymorphism on malignant diseases and have found the $\mathrm{D}$ allele to be the poor prognostic factor for several malignancies including breast cancer, intestinal type gastric cancer and prostate cancer. ${ }^{31-34}$ However, our study showed that hematologic malignancies are more prone to the existence of I allele, as in endometrial and oral cancers in which I allele has found to be the poor prognostic factor $(35 ; 36)$ that is consistent with our study in which presence of I allele increased the disease risk for 3.2 times compared to control group $(\mathrm{p}=0.008)$ (Table 3).

Additionally, the report given by Haiman et al. ${ }^{37}$ has shown that there was a positive correlation between ACE I/I genotype and the breast cancer, but stating with the discrepancy at each ethnic group. Moreover, if we took in consideration just only to AML, ALL, CML and CLL patients we achieved 6.3 times increased disease risk $(\mathrm{p}=0.001)$ (Table 4). Hence, our data represented that insertion allele might be a potent risk factor for leukemia development in our population as a selected neutral genetic marker. ${ }^{38}$

Alternatively, in vitro incubation of AML cells with an ACE inhibitor decreased the growth and colonyforming ability of AML cells in a dose-dependent manner. Adding of angiotensin II peptide to AML cells partially rescued their colony-forming ability. In addition to these, over expression of a critical RAS component, ACE (CD 143) surface antigen has shown to be over-expressed in leukemic myeloid blast cells. ${ }^{9}$ Moreover, a positive correlation has been found between the ACE and bone marrow blast count. Hence, local bone marrow RAS has been searched in acute and chronic myeloproliferative disorders and angiotensin has been suggested to act as an autocrine growth factor for AML cells. Those previous results could easily shifted us to expect a superior D allele frequency owing to higher serum ACE enzyme levels but surprisingly our result has shown that I allele has increased disease risk 3.2 times.

This may have several explanations. First of all one of the incompetence of our study was the small sample size that only 46 patients have been enrolled in the study. Larger sample sized studies would give most accurate polymorphism results. But, although we have had small sample size we have at most 4 diverse leukemia subgroups. So this deficiency might be negligible at all. Nevertheless, the local RAS might be an independent local mechanism than the circulating system. The clues for this are present in the literature that ACE is mostly a membrane-bound ectoenzyme and the cellular enzyme is known to be physiologically more important for peptide metabolism than the plasma enzyme. Abali et al. has found significant higher ACE concentrations in leukemic patient's bone marrow than in peripheral blood. ${ }^{6}$ In addition to this, Beyazit et al. has found increased mRNA expressions of renin, angiotensinogen and ACE in local bone marrow of AML patients (10) as in erythroleukemic blast cells lines (K562). ${ }^{39}$ These results are suggesting the importance and the possible underlying role of ACE I/D gene polymorphism in the malignant diseases in parallel and pertained to tissue level as if different genotypes would have effects on diverse tissues. Therefore, our result of significantly increased insertion allele frequency $(\mathrm{p}=$ 0.001 ) indicated that the level of expression of membrane-bound ACE in blastic cells was associated with the insertion/deletion polymorphism of the ACE gene (Figure 2). Thus, it could be attributed to insertion allele that increase in local ACE mRNA expression might lead to increase of effector peptide Ang-II which then could serve a potent proliferative growth affect inside leukemic bone marrow. ${ }^{40}$

Since the RAS peptides are involved in the control of cellular proliferation, Angiotensin II might have a role in the erythroid and myeloid differentiation of stem cells. Angiotensin II shows its effects in essence on AT-1 receptor, which is known as a G protein coupled 7-transmembrane receptor. At the molecular level AT-1 receptor is related to activation of lots of tyrosine kinase and non-tyrosine kinase signal transduction cascade activation such as mitogen activated protein kinase (MAPK), IP3-diachil glycerol (DAG), cAMP and JAK-STAT pathway. Additionally, Angiotensin II indirectly could activate the EGFR, 


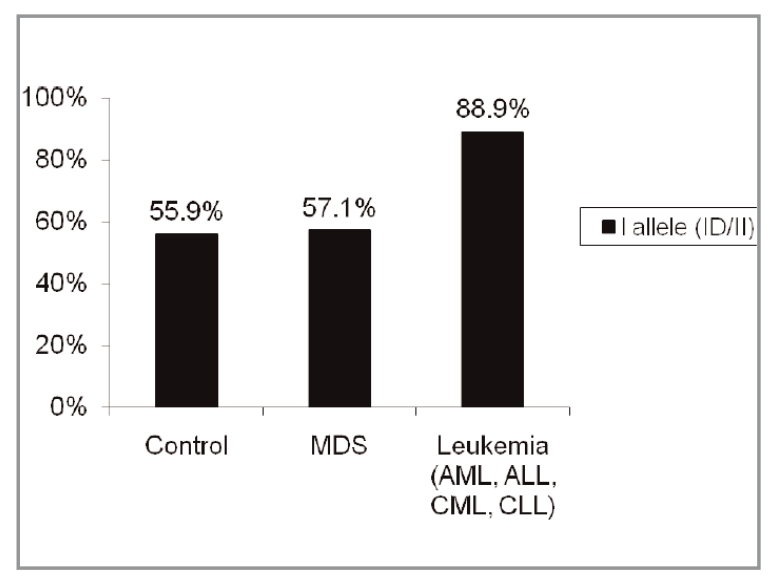

Figure 2. Comparison of $A C E I / D$ gene polymorphism between leukemia and MDS

PDGFR by receptor transactivation. ${ }^{41}$ One of the subtypes of PDGFR is ERB-B2 (HER-2/neu) that is known as an important target of breast cancer. By activating the tyrosine kinase receptors Angiotensin II could activate intracellular downstream effector molecules such as phospholipase-C and PI3-kinase, which are then result in increase of intracellular $\mathrm{Ca}^{2+}$ and Akt kinase formation, respectively. ${ }^{42}$ The latter has a potent role in cellular proliferation and inhibition of apoptosis. Activation of signal transduction pathways in the cells result in activation of intranuclear transcription factor activation such as c-JUN, cMYC and c-FOS. Heterodimerization of c-FOS and c-JUN as a posttranslational modification might result in production of transcription factor activator protein -1 (AP-1). Ang II has a role in inflammation by activation of AP- 1 and NF- $\kappa \beta$ activation over AT1 receptor. ${ }^{43}$ Additionally, it's shown that Angiotensin II could activate the JAK -STAT pathway via AT1 receptor $^{44}$, that possible relationship between the local RAS, JAK-STAT pathway and leukomogenesis has been hypothesized before ${ }^{45}$ Consequently, increased production of Angiotensin II by membrane bound ACE could result in leukemic transformation of bone marrow hematopoietic cells by gathered activation of signal transduction pathways via AT-1 receptor and/or receptor transactivation.

Additionally, ACE hyperfunction under the effect of insertion allele may lead to the acceleration of the negative hematopoietic regulator peptide AcSDKP (goralatid) metabolism, which in turn lowers its level in the bone marrow microenvironment, and finally give rise to removal of anti-proliferative effect of the peptide on hematopoietic blast cells..$^{2,6,10,46}$ As a result, insertion allele might have a role on disease development and could be used as an aberrant marker of leukemia.

Another important result of the study was for the patients who were under 50 years old. Those patients also represented increased ACE ID/II frequency as a potent risk factor for leukemia under 50 years old. The disease risk has found to be increased 4.2 times compared to the control group $(\mathrm{p}=0.015)$ [OR: 4.2, 95\% CI= 1.26-13.8)] (Table 5). This effect was not seen in the patients over 50 years old $(\mathrm{p}=1.0)$. Since the leukemia is a multifactorial diseases, important mutations occur on the patients genome during lifelong could change the effect of those polymorphisms in the patients ${ }^{47}$, but its obvious that this effect, which might result in malign disease and poor prognosis, could be seen after 50 years old and before this polymorphic genes might have crucial role in the disease development.

In conclusion, ACE ID/II genotype frequency has increased in leukemic patients. Previous studies suggested that the genetic control of ACE synthesis is probably at the transcriptional level and the regulation of ACE synthesis in cells may also be genetically determined in leukemic patients. The pathobiological consequences of the genetic polymorphism of ACE levels for leukemic cell regulation and other ACEmediated functions within the local bone marrow RAS remain to be investigated.

Acknowledgements: This work was supported in part by a grant from The Scientific and Technological Research Council of Turkey (TÜBITTAK) (No: 105S506 [SBAG-HD-94]).

Contributions: Author Ibrahim Akalin has been developed the idea, organized and lead the study, applied for the grant for financial support, studied the molecular genetics, collected and interpreted the data and wrote the manuscript. Ibrahim C. Haznedaroglu has participate in development of idea, organizing and leading the study, applications for ethical committee and grant for financial support finding patients, interpreting results and writing the manuscript, Ebru Koca has also participated in organizing and finding patient samples, interpreting the data and writing the MS. Deniz Cetiner has participate in 
finding patients, Mutlu Hayran has completed statistical analyses and interpreting the data, Ibrahim K. Onal has participate on organization of the study and grant application, Osman I. Ozcebe has participated on patient finding and Halil G. Karabulut and Ajlan Tukun has participated in designing and studying the molecular genetics and interpreting data.

Conflict of interest statement: No author has any affiliation or financial involvement with any entity with a financial interest in the work presented here. All authors have contributed significantly to the research described in the paper and have read and approved the final manuscript.

\section{REFERENCES}

1. Montgomery H, Humphries SE, Leung PS. Renin-angiotensin systems: the new frontier. Int J Biochem Cell Biol 35: 758, 2003.

2. Haznedaroglu IC, Buyukasik Y. Current evidence for the existence of a local renin-angiotensin system affecting physiological and pathological haemopoiesis in the bone marrow. Br J Haematol 99: 471, 1997.

3. Haznedaroglu IC, Tuncer S, Gursoy M. A local reninangiotensin system in the bone marrow. Med Hypotheses 46: 507-510, 1996.

4. Rodgers KE, Xiong S, Steer R, diZerega GS. Effect of angiotensin II on hematopoietic progenitor cell proliferation. Stem Cells 18: 287-294, 2000.

5. Strawn WB, Richmond RS, Ann Tallant E, et al. Reninangiotensin system expression in rat bone marrow haematopoietic and stromal cells. Br J Haematol 126: 120-126, 2004.

6. Abali H, Haznedaroglu IC, Goker H, et al. Circulating and local bone marrow renin-angiotensin system in leukemic hematopoiesis: preliminary evidences. Hematology 7: 75-82, 2002.

7. Goker H, Haznedaroglu IC, Beyazit Y, et al. Local umbilical cord blood renin-angiotensin system. Ann Hematol 84: 277-281, 2005.

8. Pinto RP, Wang KK, Khoury H, et al. Aberrant Expression of Angiotensin in acute Myeloid Leukemia. Blood 102: 2124A. 2003.

9. Aksu S, Beyazit Y, Haznedaroglu IC, et al. Over-expression of angiotensin-converting enzyme (CD 143) on leukemic blasts as a clue for the activated local bone marrow RAS in AML. Leuk Lymphoma 47: 891-896, 2006.

10. Beyazit Y, Aksu S, Haznedaroglu IC, et al. Overexpression of the local bone marrow renin-angiotensin system in acute myeloid leukemia. J Natl Med Assoc 99: 57-63, 2007.
11. Soubrier F, Alhenc-Gelas F, Hubert C, et al. Two putative active centers in human angiotensin I-converting enzyme revealed by molecular cloning. Proc Natl Acad Sci USA 85: 9386-9390, 1988.

12. Hubert C, Houot AM, Corvol P, Soubrier F. Structure of the angiotensin I-converting enzyme gene. Two alternate promoters correspond to evolutionary steps of a duplicated gene. J Biol Chem 266: 15377-15383, 1991.

13. Coates $\mathrm{D}$. The angiotensin converting enzyme (ACE). Int J Biochem Cell Biol 35: 769-773, 2003.

14. Rigat B, Hubert C, Alhenc-Gelas F, et al. An insertion/deletion polymorphism in the angiotensin I-converting enzyme gene accounting for half the variance of serum enzyme levels. J Clin Invest 86: 1343-1346, 1990.

15. Cambien F, Poirier O, Lecerf L, et al. Deletion polymorphism in the gene for angiotensin-converting enzyme is a potent risk factor for myocardial infarction. $\mathrm{Na}-$ ture 359: 641-644, 1992.

16. Rigat B, Hubert C, Corvol P, Soubrier F. PCR detection of the insertion/deletion polymorphism of the human angiotensin converting enzyme gene (DCP1) (dipeptidyl carboxypeptidase 1). Nucleic Acids Res 20: 1433, 1992.

17. Shanmugam V, Sell KW, Saha BK. Mistyping ACE heterozygotes. PCR Methods Appl 3: 120-121, 1993.

18. Tiret L, Rigat B, Visvikis S, et al. Evidence, from combined segregation and linkage analysis, that a variant of the angiotensin I-converting enzyme (ACE) gene controls plasma ACE levels. Am J Hum Genet 51: 197-205, 1992.

19. Nussbaum LR, Mclnnes RR, Willard HF. Organization of the human genome. In Thompson \& Thompson Genetics in Medicine, Sixth Edition ed. Philadelphia, Saunders, 2004, 31.

20. Suehiro $T$, Morita $T$, Inoue $M$, et al. Increased amount of the angiotensin-converting enzyme (ACE) mRNA originating from the ACE allele with deletion. Hum Genet 115: 91-96, 2004.

21. Akar N, Aras O, Omurlu K, Cin S. Deletion polymorphism at the angiotensin-converting enzyme gene in Turkish patients with coronary artery disease. Scand J Clin Lab Invest 58: 491-495, 1998.

22. Arbustini E, Grasso M, Fasani R, et al. Angiotensin converting enzyme gene deletion allele is independently and strongly associated with coronary atherosclerosis and myocardial infarction. Br Heart $\mathrm{J} 74$ : 584-591, 1995.

23. Amant C, Bauters C, Bodart JC, et al. D allele of the angiotensin I-converting enzyme is a major risk factor for restenosis after coronary stenting. Circulation 96: 56-60, 1997.

24. Bohn M, Berge KE, Bakken A, et al. Insertion/deletion (I/D) polymorphism at the locus for angiotensin I-converting enzyme and parental history of myocardial infarction. Clin Genet 44: 298-301, 1993. 
25. Ueda S, Elliott HL, Morton JJ, Connell JM. Enhanced pressor response to angiotensin I in normotensive men with the deletion genotype (DD) for angiotensinconverting enzyme. Hypertension 25: 1266-1269, 1995.

26. Danser AH, Derkx FH, Hense HW, et al. Angiotensinogen (M235T) and angiotensin-converting enzyme (I/D) polymorphisms in association with plasma renin and prorenin levels. J Hypertens 16: 1879-1883, 1998.

27. Chadwick IG, O'Toole L, Morice AH, et al. Pressor and hormonal responses to angiotensin I infusion in healthy subjects of different angiotensin-converting enzyme genotypes. J Cardiovasc Pharmacol 29: 485-489, 1997.

28. Danser AH, Deinum J, Osterop AP, et al. Angiotensin I to angiotensin II conversion in the human forearm and leg. Effect of the angiotensin converting enzyme gene insertion/deletion polymorphism. J Hypertens 17: 1867-1872, 1999.

29. van Dijk MA, Kroon I, Kamper AM, et al.The angiotensin-converting enzyme gene polymorphism and responses to angiotensins and bradykinin in the human forearm. J Cardiovasc Pharmacol 35: 484-490, 2000.

30. Danser AH. Local renin-angiotensin systems: the unanswered questions. Int J Biochem Cell Biol 35: 759-768, 2003.

31. Gonzalez-Zuloeta Ladd AM, Vasquez AA, Sayed-Tabatabaei FA, et al. Angiotensin-converting enzyme gene insertion/deletion polymorphism and breast cancer risk. Cancer Epidemiol Biomarkers Prev 14: 21432146, 2005.

32. Rocken C, Rohl FW, Diebler E, et al. The angiotensin II/angiotensin II receptor system correlates with nodal spread in intestinal type gastric cancer. Cancer Epidemiol Biomarkers Prev 16: 1206-1212, 2007.

33. Yaren A, Turgut $S$, Kursunluoglu R, et al. Insertion/Deletion polymorphism of the Angiotensin I-converting enzyme gene in patients with breast cancer and effects on prognostic factors. J Investig Med 55: 255-261, 2007.

34. Yigit B, Bozkurt N, Narter F, et al. Effects of ACE I/D polymorphism on prostate cancer risk, tumor grade and metastatis. Anticancer Res 27: 933-936, 2007.

35. Freitas-Silva M, Pereira D, Coelho C, et al. Angiotensin I-converting enzyme gene insertion/deletion polymorphism and endometrial human cancer in normotensive and hypertensive women. Cancer Genet Cytogenet 155: 42-46, 2004.

36. Vairaktaris E, Yapijakis C, Tsigris C, et al. Association of angiotensin-converting enzyme gene insertion/deletion polymorphism with increased risk for oral cancer. Acta Oncol 46: 1097-1102, 2007.

37. Haiman CA, Henderson SO, Bretsky P, et al. Genetic variation in angiotensin l-converting enzyme (ACE) and breast cancer risk: the multiethnic cohort. Cancer Res 63: 6984-6987, 2003.
38. Nussbaum LR, Mclnnes RR, Willard HF. Genetic variation in populations. In Thompson \& Thompson Genetics in Medicine, 6th ed. Philadelphia, Saunders, 2004, 95-109.

39. Koca E, Haznedaroglu IC, Acar K, et al. Renin-angiotensin system expression in the K562 human erythroleukaemic cell line. J Renin Angiotensin Aldosterone Syst 8: 145-147, 2007.

40. Campbell DJ, Habener JF. Angiotensinogen gene is expressed and differentially regulated in multiple tissues of the rat. J Clin Invest 78: 31-39, 1986.

41. Yin G, Yan C, Berk BC. Angiotensin II signaling pathways mediated by tyrosine kinases. Int $\mathrm{J}$ Biochem Cell Biol 35: 780-783, 2003.

42. Kumar V, Abbas AK, Fausto N. Growth factors. In Robbins and Cotran Pathologic Basis of Disease, 7th ed. Philadelphia, Elsevier Saunders, 2005, p. 95-118.

43. Suzuki Y, Ruiz-Ortega M, Lorenzo O, et al. Inflammation and angiotensin II. Int J Biochem Cell Biol 35: 881-900, 2003.

44. Marrero MB, Schieffer B, Paxton WG, et al. Direct stimulation of Jak/STAT pathway by the angiotensin II AT1 receptor. Nature 375: 247-250, 1995.

45. Haznedaroglu IC, Arici M, Buyukasik Y. A unifying hypothesis for the renin-angiotensin system and hematopoiesis: sticking the pieces together with the JAK-STAT pathway. Med Hypotheses 54: 80-83, 2000.

46. Haznedaroglu IC, Ozturk MA. Towards the understanding of the local hematopoietic bone marrow renin-angiotensin system. Int J Biochem Cell Biol 35: 867-880, 2003.

47. Leung PS, Fung ML, Tam MS. Renin-angiotensin system in the carotid body. Int $\mathrm{J}$ Biochem Cell Biol 35: 847-854, 2003.

\section{Correspondence}

Dr. İbrahim AKALIN

Trabzon Kadın Doğum ve

Çocuk Hastalıkları Hastanesi

61030 Yenicuma, Trabzon / TURKEY

Tel: (+90.462) 3213264 / 1156

Fax: (+90.462) 3264221

E-mail: ibrahimakalin@yahoo.com 